\title{
Productivity Enhancement of a Double Slope Solar Still Coupled with a Solar System
}

\author{
Ebrahim Hamid Hussein Al-Qadami', Abdurrasheed S. Abdurrasheed', \\ Zahiraniza Mustaffa', Y.H. Mugahed Amran ${ }^{2,3^{*}}$, Khamaruzaman W. Yusof', \\ Amimul Ahsan ${ }^{4}$
}

1 Department of Civil and Environmental Engineering, Universiti Teknologi PETRONAS, Bandar Seri Iskandar, Perak, Malaysia

2 Department of Civil Engineering, College of Engineering, Prince Sattam Bin Abdulaziz University, 11942 Alkharj, Saudi Arabia

${ }^{3}$ Department of Civil Engineering, Faculty of Engineering and IT, Amran University, 9677 Quhal, Amran, Yemen

${ }^{4}$ Department of Civil and Construction Engineering, Swinburne University of Technology, Melbourne, Australia

* Corresponding author's e-mail: m.amran@psau.edu.sa

\begin{abstract}
Water shortage is rising to become a global challenge due to the variations in climate change and population increment. Converting the seawater to potable water using the desalination technology is among the existing options highlighted by researchers. However, these processes are expensive and require much energy to operate. The solar desalination technology was reported as highly adequate since it utilizes the natural sunlight and the simple concepts of evaporation and condensation to produce the drinking water. The main challenge to date is the low productivity of the technology, which must be adequately improved in order to enhance productivity and optimize performance. In this study, the productivity and efficiency of conventional double slope solar still were assessed using a solar system. Two solar still models (active and passive) were fabricated with the same evaporation and condensation areas. The troughs were made of stainless steel with dimensions of $50 \times 32 \times 5 \mathrm{~cm}$. In turn, while the cover was made of glass with dimensions of $48 \times 60 \times 0.3 \mathrm{~cm}$ and the inclination angle was $60^{\circ}$. In addition, the solar system consisted of two solar panels with $50 \mathrm{~W}$ capacity each, one battery of $100 \mathrm{Ah}-12 \mathrm{~V}$, a charging controller of $30 \mathrm{~A}$, and a single immersed DC water heater of $50 \mathrm{~W}-12 \mathrm{~V}$ capacity. Both models were tested simultaneously for two sunny days, 24 hours each. The results showed that the water productivity of the active solar still was $55 \%$ higher than that of the passive solar still. On $15^{\text {th }}$ July, the total amounts of solar still productivity were $7.85 \mathrm{~L} / \mathrm{m}^{2} / \mathrm{d}$ and $19.3 \mathrm{~L} / \mathrm{m}^{2} / \mathrm{d}$ for active and passive stills, respectively. This is due to the existence of the heating element in the active still which allowed it to produce water for 24 hours continuously. Moreover, the trough temperature was found to be the highest for both models, because it was made from steel. Finally, the produced water in both cases was found to be directly proportional to such parameters as solar radiation intensity and ambient temperature.
\end{abstract}

Keywords: active solar still, solar still productivity, desalination, solar system, passive solar still.

\section{INTRODUCTION}

The availability of clean, potable drinking water is among the factors fundamental to the human existence. The shortage in supply of this valuable resource around the world is considered a great challenge [Kabeel et al. 2019, Al-Qadami et al. 2019]. Malaysia is not an exception, as some parts of the country are facing difficulties in supplying fresh water because of the presence of a high concentration of toxic chemicals and heavy metals, which require expensive processes such as desalination or reverse osmosis [Jasrotia et al. 2013]. With enough sunshine in the country, solar desalination has been considered as a great option to solve these problems and ensure adequate potable water productivity at affordable prices [Ahsan et al. 2014, Syuhada et al. 2013]. Solar 
desalination had been identified by researchers as a viable option to produce healthy and safe drinking water from any source, including brackish, river, sea and other contaminated sources of water, using the simple concepts of evaporation and condensation. In terms of the efficiency improvement, in Saudi Arabia, Al-Garni [2012] reported the use of external heat energy sources as a supplement to improve the basin temperature and enhance productivity. In his experiment, he used two heaters of capacities of $500 \mathrm{~W}$ each in order to increase the evaporation in the basin. A yield of $11.8 \mathrm{~L} / \mathrm{m}^{2} / \mathrm{d}$ was obtained, which is equivalent to $370 \%$ improvement when compared with the conventional solar still productivity of $2.5 \mathrm{~L} /$ $\mathrm{m}^{2} / \mathrm{d}$. Additionally, in Muscat, Oman, an inverted absorber solar still was developed and it was found to produce a yield of $6.3 \mathrm{~L} / \mathrm{m}^{2} / \mathrm{d}$ which is an enhancement in productivity by about $192 \%$ [Dev et al. 2007]. Additionally, storage materials such as sand and rock particles were found in the literature to function as absorption materials and as internal sources of energy. For example, sawdust was used in Egypt and was found to increase the productivity by $35 \%$ according to Mohamad et al. [2005]. Murugavel et al. [2010] also reported that in India, the Quartzite rock was added to the basin of the still as a heat absorption material and was found to produce a yield of $3.66 \mathrm{~L} / \mathrm{m}^{2} / \mathrm{d}$, which is equivalent to $17.6 \%$ improvement.

A lot of work had been carried out on the active and passive solar stills with different configurations using both theoretical and experimental methods in order to improve the water productivity. For example, in Malaysia, triangular solar still (TrSS) was fabricated by Ahsan et al. [2014] with a tilt angle of $60^{\circ}$ using a black Perspex sheet in the basin, as well as a polythene cover that is transparent in nature and produced a yield of 1.55 $\mathrm{L} / \mathrm{m}^{2} /$ d. In Jordan, a solar still experiment was conducted to estimate the optimum tilt angle that will produce the highest yield. A tilt of $35^{\circ}$ was found to improve productivity by about $226 \%$ to a yield of $6.2 \mathrm{~L} / \mathrm{m}^{2} / \mathrm{d}$ [Akash et al. 2010]. A similar experiment was conducted in Bahrain, as reported by Al-Karaghouli and Alnaser [2004] to compare the efficiency of a double and a single basing solar still. The double solar still showed an improvement of $37 \%\left(2.91 \mathrm{~L} / \mathrm{m}^{2} / \mathrm{d}\right)$ when compared with the yield single basin. Ismail [2009] also reported a potable hemispherical solar still which produced a yield of $5.7 \mathrm{~L} / \mathrm{m}^{2} / \mathrm{d}$. From the findings above, it can be concluded that there is a high possibility of a reasonable improvement in the performance of the solar still technology in terms of the design configuration and yield. So far, the conventional solar still averagely produce an average of $2-5 \mathrm{~kg} / \mathrm{m}^{2} /$ day which is not enough for one person. In order to improve the output productivity of the system, some modifications are needed.

In this paper, the productivity efficiency of an active double slope solar still assessed with a solar system was investigated and compared with a passive solar still. In order to enhance the productivity of the active still, $50 \mathrm{~W} 12 \mathrm{~V}$ low power immersed water heater was placed inside the trough. A $100 \mathrm{Ah} 12 \mathrm{~V}$ rechargeable solar battery was used to store the power from the two solar panels and provide electricity for the water heater. Different parameters were measured during the filed experiments, including solar radiation intensity, ambient, in-cover, out-cover, water, trough temperatures and hourly water productivity. Further, the distilled water quality was assessed and tested to find out the ability of solar still to produce drinkable water.

\section{MATERIALS AND METHODS}

In this study, for the purpose of field experiments, two solar still models (passive and active) were designed and fabricated. Both models had the same evaporation area (water basin) with dimensions of $50 \times 32 \times 5 \mathrm{~cm}$, made from stainless steel and painted black. The condensation area (top cover) was from the glass with dimensions of $48 \times 60 \times 0.3 \mathrm{~cm}$ and the cover angle between the horizontal plane and the cover was selected to be $60^{\circ}$. The collecting channels were made of aluminium and placed at all cover sides with an inclination angle of $1^{\circ}$. Two collecting containers were placed underneath the model for collecting the produced water. Figure 1 below shows the schematic of the basic components and dimensions of the models.

The two models have the same characteristics in terms of dimensions and materials of construction. However, the active solar still was modified and assessed with an external heating source. Two solar panels of $50 \mathrm{~W}$ each were connected with one (1) battery of $100 \mathrm{Ah}$ and $12 \mathrm{~V}$ for supplying energy to the heating element with the capacity of $50 \mathrm{~W}$, immersed at the midpoint of the water basin. Table 1 shows the solar system 


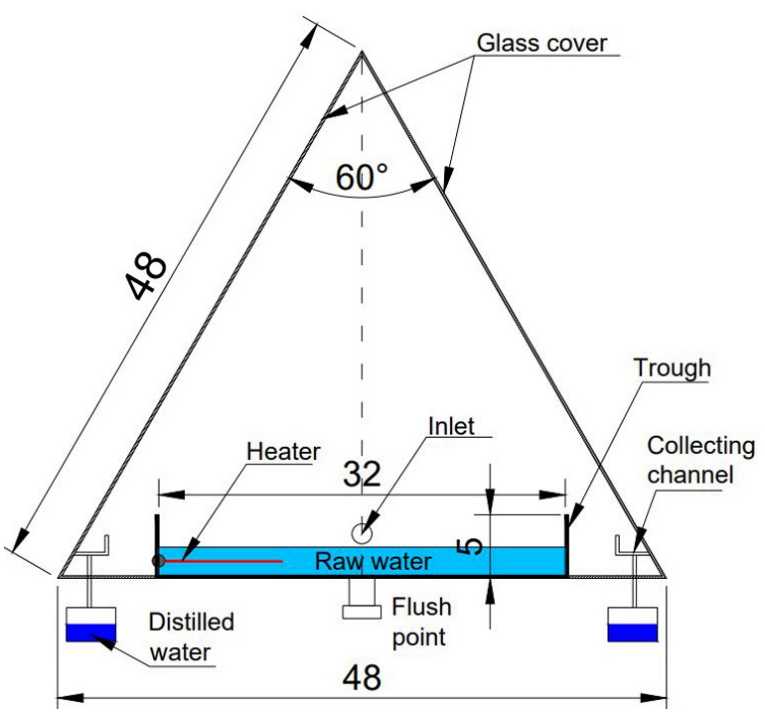

Fig. 1. Schematic of the Solar still basic components and dimensions

components and water heater specifications. Figures 2 and 3 show the active and passive solar stills, respectively.

The field tests were carried out at Universiti Teknologi Petronas (UTP) solar field, Seri Iskandar, Malaysia for 2 sunny days. The water samples were collected from Village 6, UTP Lake. Different water quality parameters were tested, including $\mathrm{pH}$, Turbidity, Nitrate, Sulphate, and Iron before and after the desalination process. Figure 4 shows the water sample before and after the desalination process. In turn, the schematic diagram of active solar still was shown in Figure 5.

During the field experiments, different parameters were measured and recorded, including water temperature $(\mathrm{Tw})$, basin temperature $(\mathrm{Tb})$, in-cover temperature (Tic), out-cover temperature (Toc) and ambient temperature (Ta), solar radiation intensity (SR) and water productivity. Thermocouples were placed at the desired locations for temperature measurements, while a solar intensity meter was used to measure the solar radiation.

\section{Experiment procedure}

By 09:00 AM, the test was started by filling both solar still models with raw water samples through the inlet point. Each model was filled with water to the depth of $2 \mathrm{~cm}$, then the inlet ports were closed tightly. Both models were run for 24 hours during the day and night. The

Table 1. Solar system components and water heater specifications

\begin{tabular}{|l|c|c|c|}
\hline \multirow{2}{*}{ Solar panel } & Unit & Dimensions $(\mathrm{cm})$ & Power (W) \\
\cline { 2 - 4 } & 2 & $60 \times 60$ & 50 \\
\hline \multirow{2}{*}{ Charge controller } & Unit & Current (A) & Voltage (V) \\
\cline { 2 - 4 } & 1 & 30 & Voltage (V) \\
\hline \multirow{2}{*}{ Heating element } & Unit & Power (W) & 12 \\
\cline { 2 - 4 } & 1 & 50 & Charging current (A) \\
\hline \multirow{2}{*}{ Battery } & Unit & Energy (Ah·V) & 30 \\
\cline { 2 - 4 } & 1 & $100 \cdot 12$ & \\
\hline
\end{tabular}

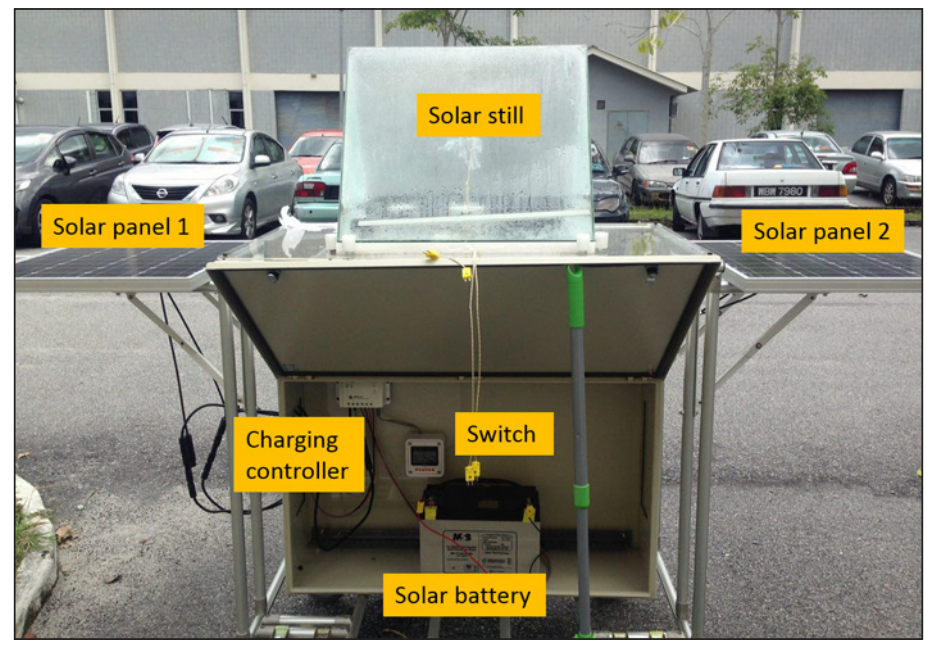

Fig. 2. Active solar still setup 


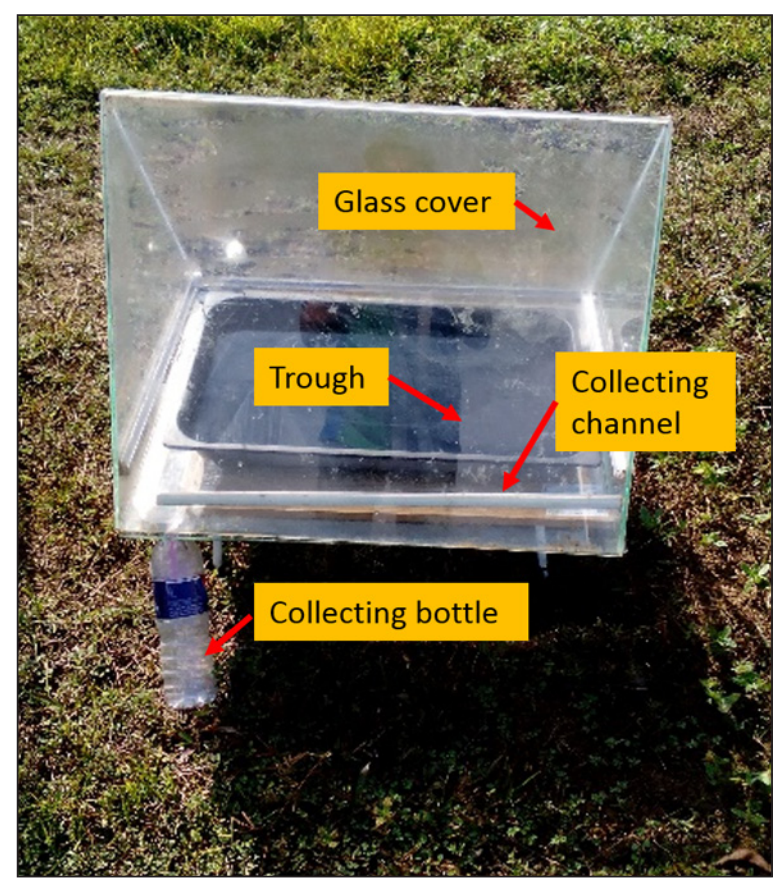

Fig.3. Passive solar still setup

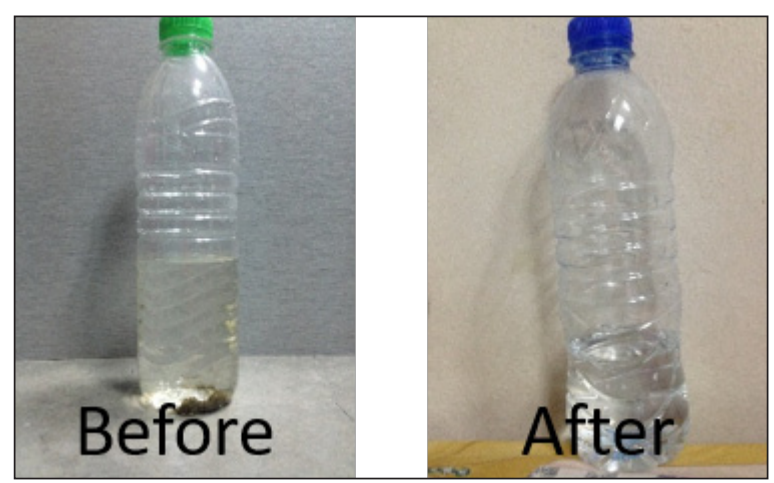

Fig. 4. Lake water before and after desalination temperature and solar radiation intensity measurements were taken every 20 minutes then the hourly average was calculated. For water productivity, the measurements were recorded each hour during the day and night. The water heating element inside was made active for 24 hours. The battery was charged using solar energy a day to the commencement of the experiments.

\section{RESULTS AND DISCUSSION}

\section{Hourly variation of water productivity}

The water produced from both solar still models (active and passive) was measured hourly using a measuring cylinder for 24 hours. Figures 6 and 7 show the amount of water that was collected each hour for the active and passive solar stills on $9^{\text {th }}$ and $15^{\text {th }}$ July, respectively. From the results, it can be noticed that the productivity of the active solar still was greater than that of the passive solar still throughout the experiment. This was due to the existence of the water heater in the active still which was working for 24 hours to keep the water at high temperature. In addition, during the night, the passive solar still productivity was so low due to the cold weather at night and the fact that there was no alternative source of the heating energy. On the other hand, the active solar still productivity during the night was high compared with the passive one and the productivity was nearly consistent. Moreover, the maximum water productivity of the active solar still was observed on $15^{\text {th }}$ July at 02:00 PM which was about $390 \mathrm{ml}$,

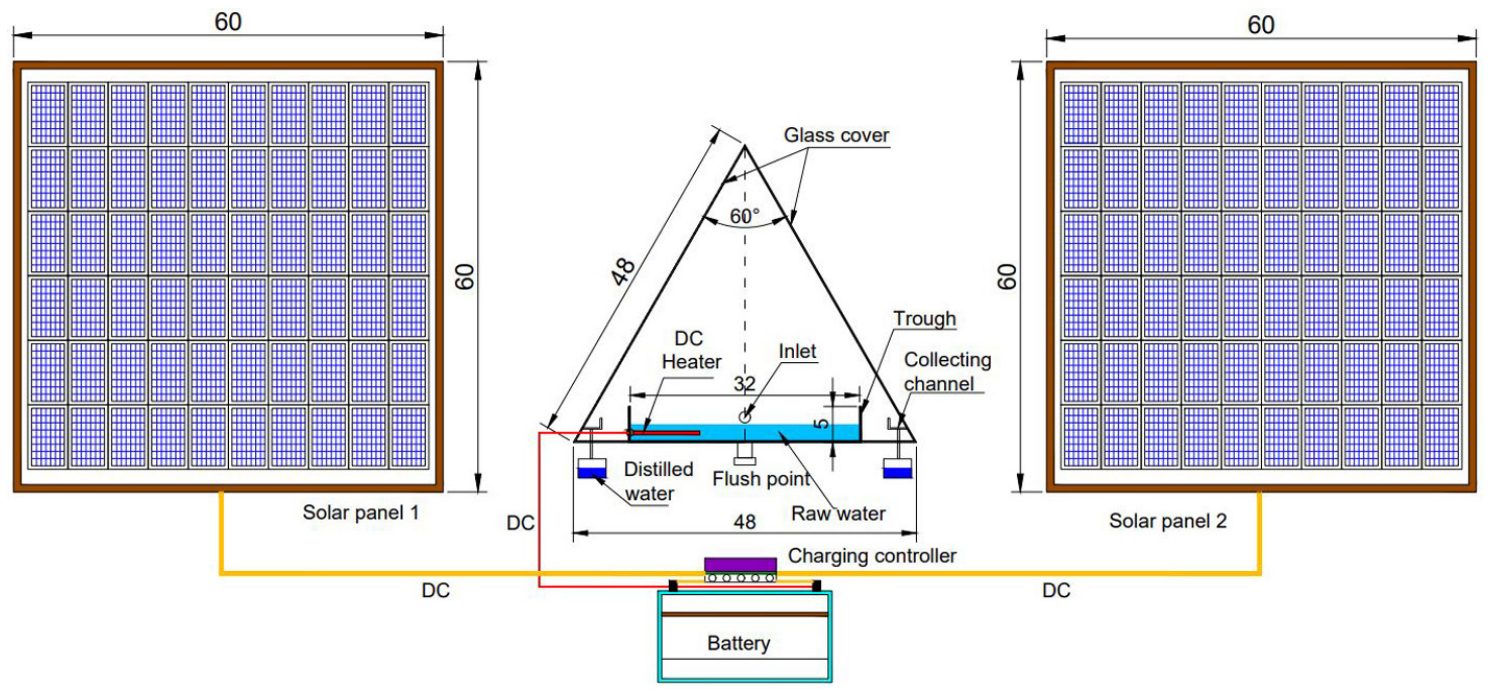

Fig. 5. Schematic diagram of the active solar still 


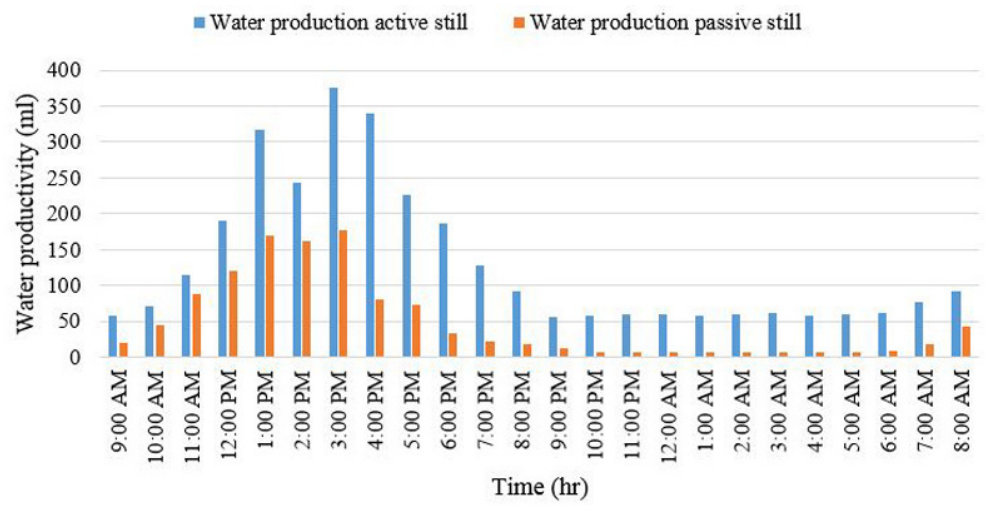

Fig. 6. Hourly variations of water productivity for the active and passive solar stills $-9^{\text {th }}$ July

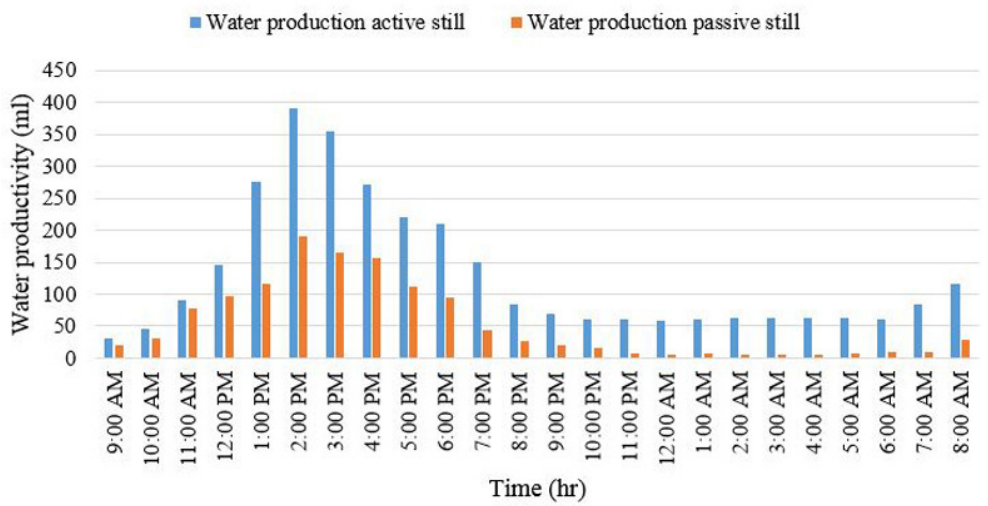

Fig. 7. Hourly variations of water productivity for the active and passive solar stills $-15^{\text {th }}$ July

while it was $190 \mathrm{ml}$ for the passive solar still on the same day. The results pattern shows a great overlap with the results of Riahi et al. [2016].

\section{Hourly variation of water productivity and temperatures}

Generally, the amount of distilled water from both solar stills was following the inside and outside temperature pattern in terms of increase or decrease in values. On $9^{\text {th }}$ July, the temperatures of water, in-cover, out-cover, basin, and ambient were recorded for both solar stills as shown in Figures 8 and 9. The results showed that in both stills, the trough temperatures were highest during the day time when compared with other recorded temperatures. This is due to the high ability of stainless steel (basin material) to absorb heat. However, during the night-time, the basin and water temperature were almost the same in the passive solar still, but the water temperature was higher than the basin and another part in the active solar still. This is due to the consistent heat from the water heater. This record shows a good agreement with the work of Riahi et al. [2016], Al-Qadami et al. [2019] and Muftah et al. [2014].

On $15^{\text {th }}$ July, the same measuring procedures were performed during the day and night times. In the case of the passive solar still, the results showed that at 02:00 PM the output was at the highest point, and the water and basin temperatures were at the maximum values $\left(57\right.$ and $59^{\circ} \mathrm{C}$, respectively), as shown in Figure 10. While the active solar still maximum distilled water productivity was at 02:00 PM, which was the same time of recording the highest basin and water temperatures, as shown in Figure 11.

\section{Hourly variation of water productivity and solar radiation intensity}

Figures 12 and 13 show the relationship between the solar radiation intensity (SR) and the productivity of the solar still on the $9^{\text {th }}$ and $15^{\text {th }}$ July, respectively. From the results, it is clear that the produced water amount increases and decreases gradually following the solar radiation intensity pattern. On the $9^{\text {th }}$ July, 09:00 AM 


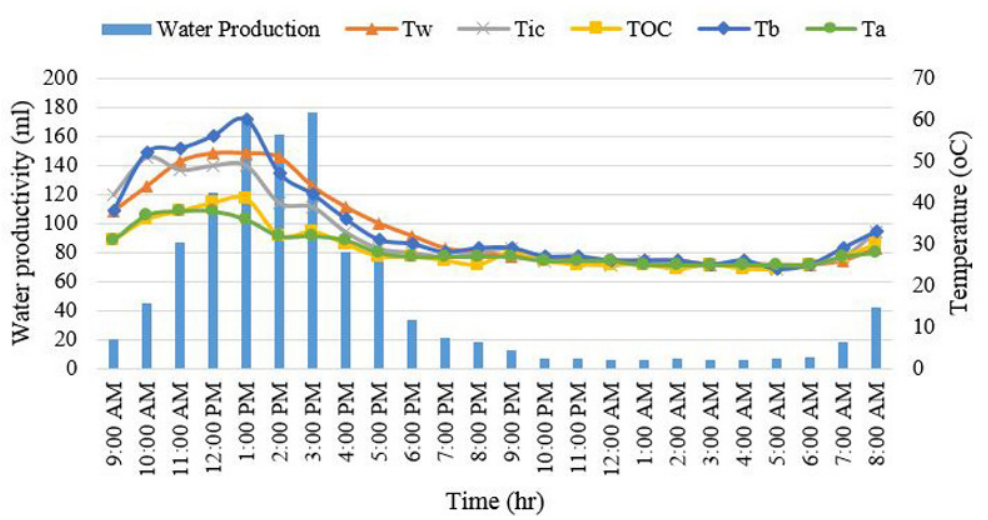

Fig. 8. Hourly variations of water productivity and temperatures for the passive solar still $-9^{\text {th }}$ July

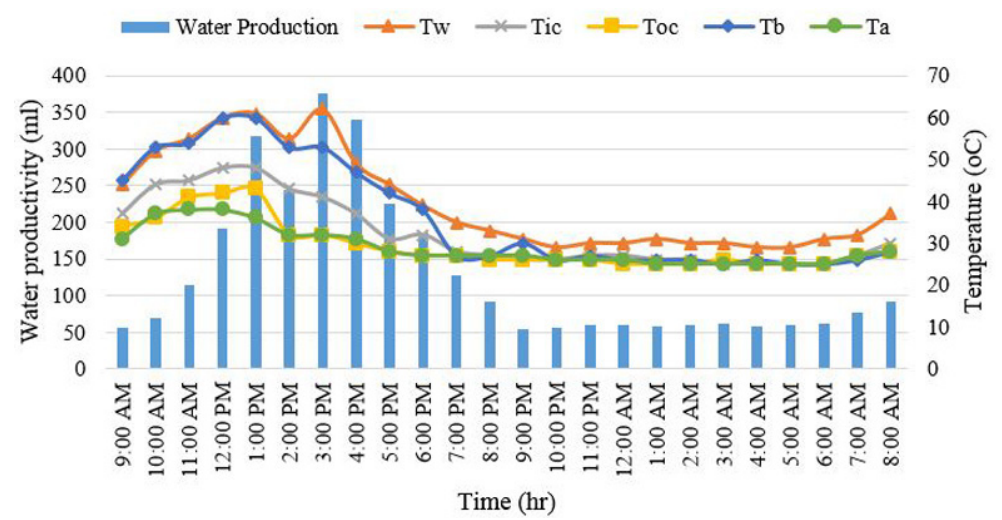

Fig. 9. Hourly variations of water productivity and temperatures for the active solar still $-9^{\text {th }}$ July

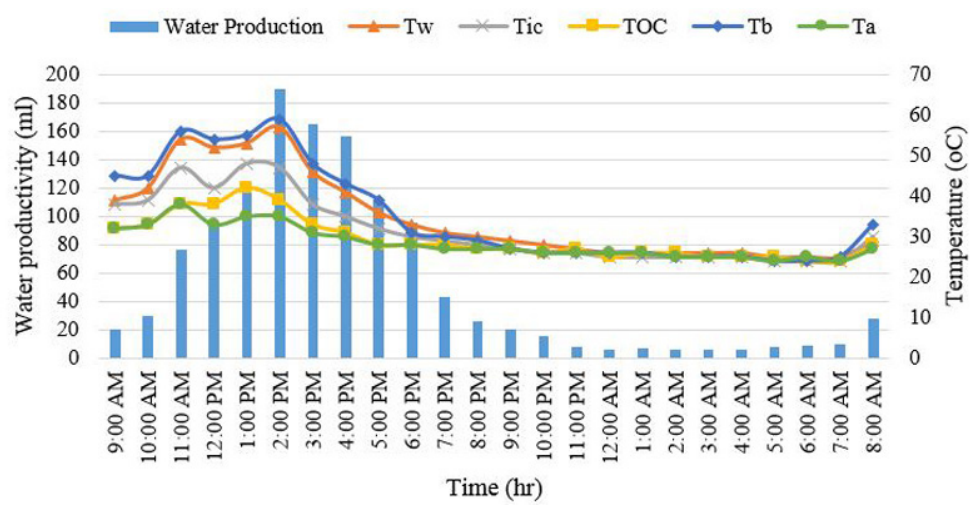

Fig. 10. Hourly variations of water productivity and temperatures for the passive solar still $-15^{\text {th }}$ July

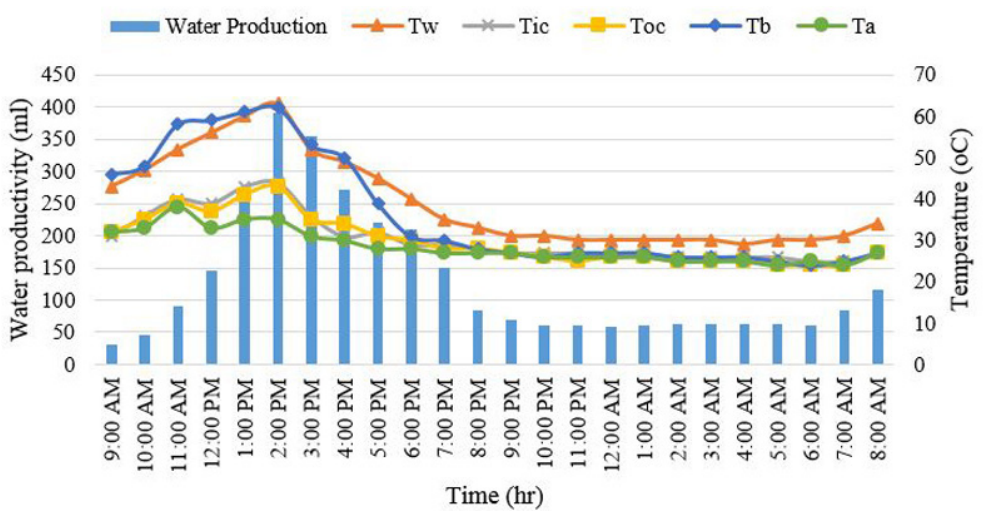

Fig. 11. Hourly variations of water productivity and temperatures for the active solar still $-15^{\text {th }}$ July 


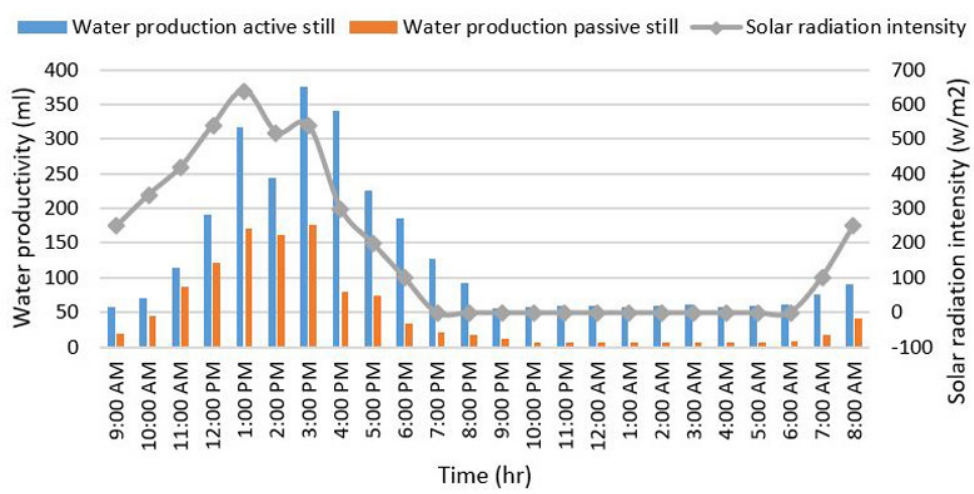

Fig. 12. Hourly variations of water productivity and solar radiation intensity for the active and passive solar stills $-9^{\text {th }}$ July

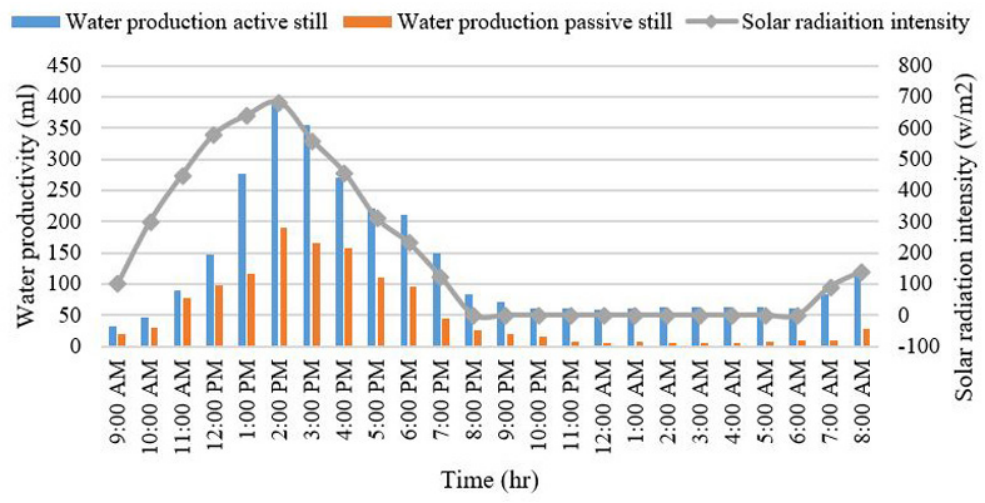

Fig. 13. Hourly variations of water productivity and solar radiation intensity for the active and passive solar stills $-15^{\text {th }} \mathrm{July}$

solar radiation intensity was $250 \mathrm{~W} / \mathrm{m}^{2}$ then it increased to reach the maximum value of 640 $\mathrm{W} / \mathrm{m}^{2}$ at 01:00 PM, after which it decreased gradually to reach the minimum value $0 \mathrm{~W} / \mathrm{m}^{2}$ at 07:00 PM. The solar radiation intensity was at 0 value through the night until the next day at 07:00 AM then it started to increase again as shown in the results. On the $15^{\text {th }}$ July, solar radiation intensity reached the maximum value of $680 \mathrm{~W} / \mathrm{m}^{2}$ at 02:00 PM and the water produced at the same time was at its peak with values of $390 \mathrm{ml}$ for active solar still and $190 \mathrm{ml}$ for passive solar still. This observation agrees with the results of Al-Qadami et al. [2019].

\section{Hourly variation of solar radiation intensity and temperatures}

Figures 14 and 15 show the relationship between the solar radiation intensity and temperatures on the $9^{\text {th }}$ and $15^{\text {th }}$ July, respectively. Both results showed that the water temperature in active solar still was higher than the temperature of passive solar still during the whole day and night. Furthermore, it can be observed that the temperatures in both charts are following the solar intensity pattern. The maximum solar radiation intensities achieved were 640 and $680 \mathrm{~W} / \mathrm{m}^{2}$ on $9^{\text {th }}$ and $15^{\text {th }} \mathrm{July}$, respectively, and the minimum value was $0 \mathrm{~W} / \mathrm{m}^{2}$ during the night-time.

\section{Water quality results}

Different water quality parameters, namely $\mathrm{pH}$, Turbidity, Nitrate, sulphate, and Iron were selected to be tested before and after the desalination process. Table 2 shows the test results of the water quality parameters for the lake water samples in both the passive and active solar stills. A good percentage of removal was noticed for all parameters. Sulphate was found to be the highest parameter which was affected by the desalination process. Furthermore, the produced water quality parameters were compared with the Malaysian drinking water standards and the results showed that the distilled water specifications were lower than the standards. 


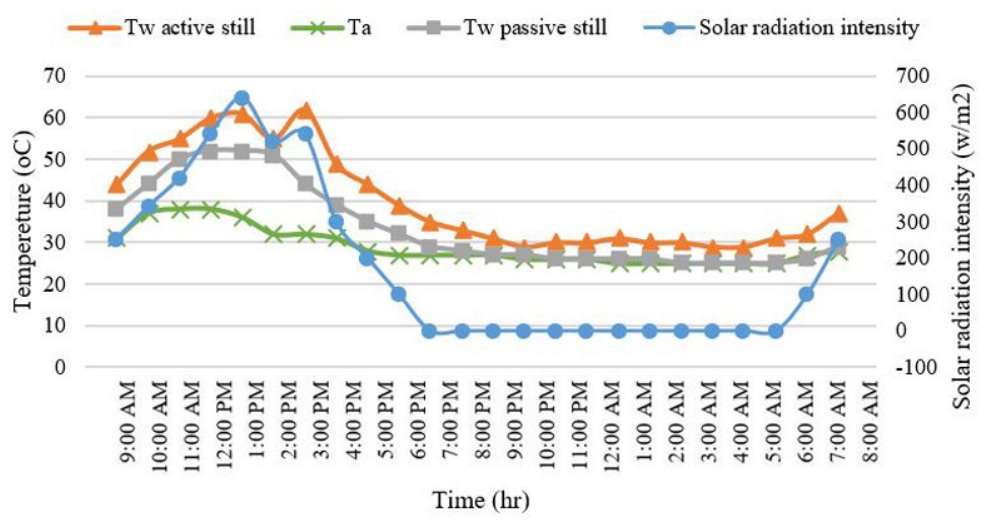

Fig. 14. Hourly variations of temperatures and solar radiation intensity for the active and passive solar stills $-9^{\text {th }}$ July

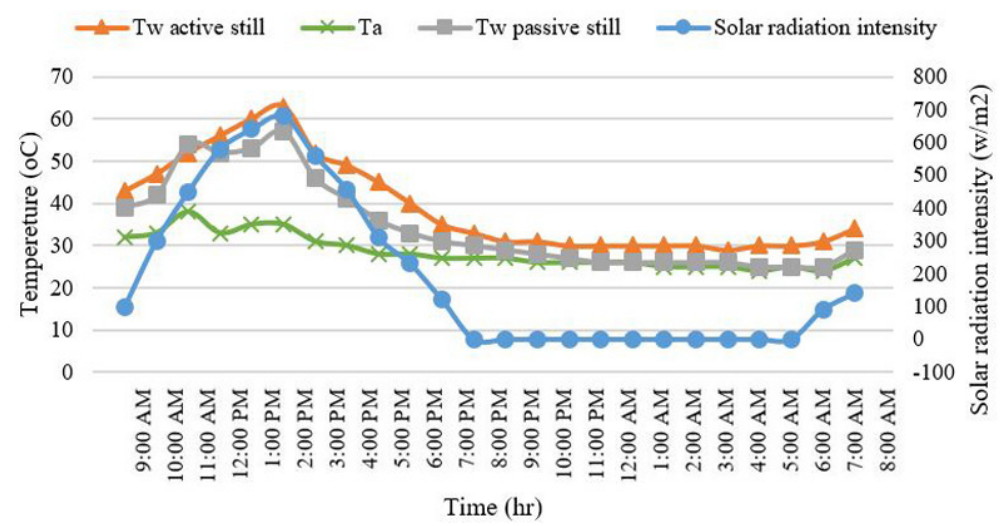

Fig. 15. Hourly variations of temperature and solar radiation intensity for the active and passive solar stills $-15^{\text {th }}$ July

Table 2. Water quality parameters before and after desalination

\begin{tabular}{|l|c|c|c|c|c|}
\hline \multicolumn{1}{|c|}{ Parameter } & Raw water & Passive solar still & Active solar still & Removal \% & $\begin{array}{c}\text { Malaysian drinking water } \\
\text { standard (2005) }\end{array}$ \\
\hline $\mathrm{pH}$ & 6.72 & 6.62 & 6.59 & 1.93 & 6 -Sep \\
\hline Turbidity (NTU) & 33.61 & 1.6 & 1.43 & 95.74 & 25 \\
\hline Nitrate $(\mathrm{mg} / \mathrm{L})$ & 2.48 & 0.45 & 0.38 & 84.67 & 50 \\
\hline Sulphate $(\mathrm{mg} / \mathrm{L})$ & 18.72 & 0.2 & 0 & 99.46 & 800 \\
\hline Iron $(\mathrm{mg} / \mathrm{L})$ & 0.94 & 0.1 & 0.07 & 92.55 & 3 \\
\hline
\end{tabular}

\section{CONCLUSIONS}

In this study, the active and passive solar still models were fabricated and tested to investigate the yield and efficiency of both models in terms of the water quality. The active solar still was supplied with an external source of heat through an external solar system to enhance its productivity. From the field tests the following conclusions were drawn:

1. Distilled water produced by the active solar still increased by $55 \%$ compared with the water production of passive solar still. This is due to the immersed water heater which was placed inside the active solar still. This heater allowed the model to produce water along 24 hours and at the same time increased the water temperature when compared with the passive solar still.

2 . The maximum production rate was on the $15^{\text {th }}$ July with amounts of $190 \mathrm{ml}$ and $390 \mathrm{ml}$ for active and passive solar stills. In turn, the productivity was $176 \mathrm{ml}$ and 376 on $9^{\text {th }}$ July for the active and passive solar stills.

3. The model outputs were found to be directly proportional to such parameters as solar radiation intensity and ambient temperature. 
4. Further, a good percentage of removal of some contaminants was noticed when compared with raw produced water quality parameters. This is evidence of the effectiveness of the solar still system.

5. This still can be applied to treat industrial effluent, landfill leachate and various types of wastewater.

\section{Acknowledgment}

The authors greatly appreciate the financial support given by the Deanship of Scientific Research at Prince Sattam bin Abdulaziz University, Alkharj, Saudi Arabia; and the supervision and the research environment provided by the Universiti Teknologi PETRONAS, Malaysia, for this research.

\section{REFERENCES}

1. Ahsan A., Imteaz M., Thomas U.A., Azmi M., Rahman A., Daud N.N. 2014. Parameters affecting the performance of a low cost solar still. Applied Energy, 114, 924-930.

2. Akash B.A., Mohsen M.S., Nayfeh W. 2000. Experimental study of the basin type solar still under local climate conditions. Energy Conversion and Management, 41(9), 883-890.

3. Al-Garni A.Z. 2012. Productivity enhancement of solar still using water heater and cooling fan. Journal of Solar Energy Engineering, 134(3), p. 031006.

4. Al-Karaghouli A., Alnaser W. 2004. Experimental comparative study of the performances of single and double basin solar-stills. Applied Energy, 77(3), 317-325.

5. Al-Qadami E.H.H., Ahsan A., Abdurrasheed A.S., Mustaffa Z., Yusof K.W., Takaijudin H., Malek M.A. 2019. Yield efficiency evaluation of double slope solar stills connected with external spiral copper for potable water production. Journal of Ecological Engineering, 20(7), 176-186.

6. Dev R., Abdul-Wahab S.A., Tiwari G. 2011. Performance study of the inverted absorber solar still with water depth and total dissolved solid. Applied Energy, 88(1), 252-264.

7. Ismail B.I. 2009. Design and performance of a transportable hemispherical solar still. Renewable Energy, 34(1), 145-150.

8. Jasrotia S., Kansal A., Kishore V. 2013. Application of solar energy for water supply and sanitation in arsenic affected rural areas: a study for kaudikasa village, India, Journal of Cleaner Production, 60, 102-106.

9. Kabeel A., Dawood M.M.K., Ramzy K., Nabil T., Elnaghi B. et al. 2019. Enhancement of single solar still integrated with solar dishes: An experimental approach. Energy Conversion and Management, 196, 165-174.

10. Mohamad M., Soliman S., Abdel-Salam M., Hussein H. 1995. Experimental and financial investigation of asymmetrical solar stills with different insulation. Applied Energy, 52(2-3), 265-271.

11. Muftah A.F., Alghoul M., Fudholi A., Abdul-Majeed M., Sopian K. 2014. Factors affecting basin type solar still productivity: A detailed review. Renewable and Sustainable Energy Reviews, 32, 430-447.

12. Murugavel K.K., Sivakumar S., Ahamed J.R., Chockalingam K.K., Srithar K. 2010. Single basin double slope solar still with minimum basin depth and energy storing materials. Applied Energy, 87(2), 514-523,

13. Riahi A., Wan Yusof K., Mahinder Singh B.S., Isa M.H., Olisa E., Zahari N.A.M. 2016. Sustainable potable water production using a solar still with photovoltaic modules-ac heater. Desalination and Water Treatment, 57(32), 14 929-14944.

14. Syuhada N., Ahsan A., Thomas U.A., Imteaz M., Ghazali A.H. et al. 2013. A low cost solar still for pure water production. J. Food Agric. Environ., 11(2), 990-994. 